ABDI: Jurnal Pengabdian dan Pemberdayaan Masyarakat ISSN: 2656-369X (Print), 2684-8570 (Online)

Volume 3 No. 2, Desember 2021

http://abdi.ppj.unp.ac.id/index.php/abdi

Email: abdi@ppj.unp.ac.id

DOI: https://doi.org/10.24036/abdi.v3i2.148

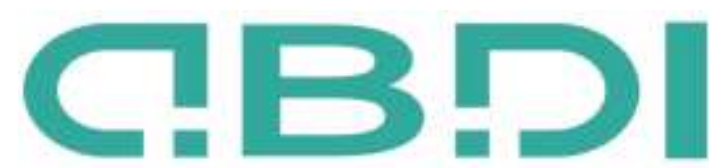

ABDE JURNAL PENGABDIAN DAN PEMBERDAYMN MASYARAKAT

\title{
Pelatihan Public Speaking dan Pemanfaatan Media Sosial pada Komunitas Women March Yogyakarta
}

\author{
Irene Santika Vidiadari' ${ }^{1}$, Rebekka Rismayanti ${ }^{2}$, Immanuel Dwi Asmoro Tunggal $^{3}$ \\ 1,2,3Prodi Ilmu Komunikasi, Universitas Atma Jaya Yogyakarta \\ E-mail: irene.vidiadari@uajy.ac.id
}

\begin{abstract}
Abstrak
Gerakan sosial berbasis gender merupakan sebuah aktivitas di ranah publik yang memperjuangkan kesetaraan hak, penghapusan kekerasan kepada perempuan, maupun perjuangan untuk mengikis diskriminasi gender. Praktik gerakan berbasis gender juga mengacu pada kegiatan orasi di ruang-ruang publik, aksi turun ke jalan dan menyuarakan tuntutan. Untuk mewujudkan gerakan ini, maka seorang orator setidaknya perlu memiliki kapasitas untuk menyampaikan pesan. Dalam hal ini pengetahuan, kemampuan menguasai audiens dan kemampuan berstrategi menggunakan media untuk menyuarakan ide-idenya. Pelatihan Public Speaking dan pendampingan pemanfaatan media ini ditujukan untuk komunitas Women March di Yogyakarta agar komunitas dapat memanfaatkan beragam media sosial yang mereka miliki untuk menyuarakan perjuangan mereka. Pelatihan dilaksanakan dengan menggabungkan dua metode: pemaparan teori dan praktik kepada para anggota komunitas. Pelatihan terdiri dari tiga materi besar: (1) pemahaman tentang gender dan seksualitas untuk memberikan pengetahuan seputar isu gender, (2) public speaking untuk memahami teknik berbicara di depan umum, (3) pemanfaatan media sosial untuk memberikan pengetahuan terkait pengelolaan pesan di media sosial. Melalui kegiatan ini, komunitas mampu mengaplikasikan kecakapan public speaking pada kegiatan orasi maupun pada unggahan media sosialnya.

Kata kunci: Gender, Gerakan Sosial, Konten Media Sosial, Public Speaking

\section{Abstract}

The gender's movement is an activity in the public sphere that fights for equal rights, the elimination of violence against women, and the struggle to eradicate gender discrimination. The practice of gender-based movements also refers to orations in public spaces, taking to the streets and voicing demands. To realize this movement, an orator at least needs to have the capacity to convey a message. In this case, knowledge, the ability to master the audience and strategically use the media to voice their ideas. This Public Speaking training and media utilization assistance is intended for the Women March community in Yogyakarta to take advantage of the various social media they have to voice their struggles. The training is carried out by combining two methods: presenting theory and practice to community members. The training consists of three primary materials:(1) Understanding of gender and sexuality to provide knowledge about gender issues, (2) Public speaking to understand public speaking techniques, (3) Using social media to provide knowledge related to managing messages on social media. The community can apply public speaking skills in oration activities and on social media uploads through this activity.
\end{abstract}

Keyword: Gender, Public Speaking, Social Media Content, Social Movement

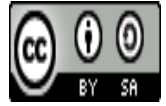




\section{Pendahuluan}

Ketidakadilan gender di Indonesia merupakan persoalan yang tidak pernah tuntas. Tindakan diskriminasi hingga kekerasan masih sering dialami oleh perempuan dan gender minoritas. Catatan dari Komnas Perempuan, pada tahun 2019 mencatat tindakan kekerasan pada perempuan meningkat. Kasus kekerasan yang dilaporan mencapai 431.471 kasus kekerasan (Purnamasari, 2020). Diskriminasi yang dialami perempuan tidak hanya berupa kekerasan fisik, namun juga kekerasan seksual dan adanya kebijakan yang diskriminatif (Narda, 2019). Berdasarkan data ini, dapat dilihat bahwa upaya-upaya untuk menekan kekerasan kepada perempuan belum membuahkan hasil yang signifikan. Salah satu upaya yang dilakukan untuk menyuarakan hak perempuan dan isu kekerasan gender adalah melalui komunitas gerakan sosial, khususnya yang bergerak pada isu gender. Gerakan perempuan merupakan salah satu bentuk gerakan sosial di ranah publik dan bertujuan untuk menyuarakan hak-hak perempuan, penghapusan kekerasan kepada perempuan, maupun perjuangan untuk mengikis diskriminasi gender dalam beragam manifestasi lainnya. Saat ini, gerakan berbasis gender juga merambah ke ruang-ruang maya. Praktik gerakan berbasis gender juga mengacu pada kegiatan orasi di ruang-ruang publik, aksi turun ke jalan dan menyuarakan tuntutan. Komunitas Women March Yogyakarta merupakan komunitas yang bergerak pada isu-isu gender. Komunitas ini diinisiasi oleh anak muda melalui parade di jalan yang dilaksanakan setiap 8 Maret, tepat pada hari perempuan internasional.

Pada saat parade, Women March Yogyakarta melakukan orasi yang berisi pesan-pesan mengenai kesetaraan hak, pesan untuk tidak mendiskriminasi, dan lain-lain. Pada saat orasi, komunitas ini memiliki tujuan agar audiens dapat menangkap pesan dengan baik. Untuk itu, orator perlu memiliki kecakapan komunikasi publik yang baik. Hal ini justru menjadi akar masalah yang dihadapi oleh komunitas, tidak hanya persoalan metode penyampaian pesan, kapasitas pengetahuan juga menjadi masalah. Hasil diskusi dengan pengurus Women March Yogyakarta menghasilkan simpulan bahwa terdapat tiga masalah utama yang dihadapi oleh komunitas jika mereka ingin berpartisipasi dalam gerakan sosial berbasis gender. Ketiga masalah tersebut dapat dilihat melalui bagan berikut:

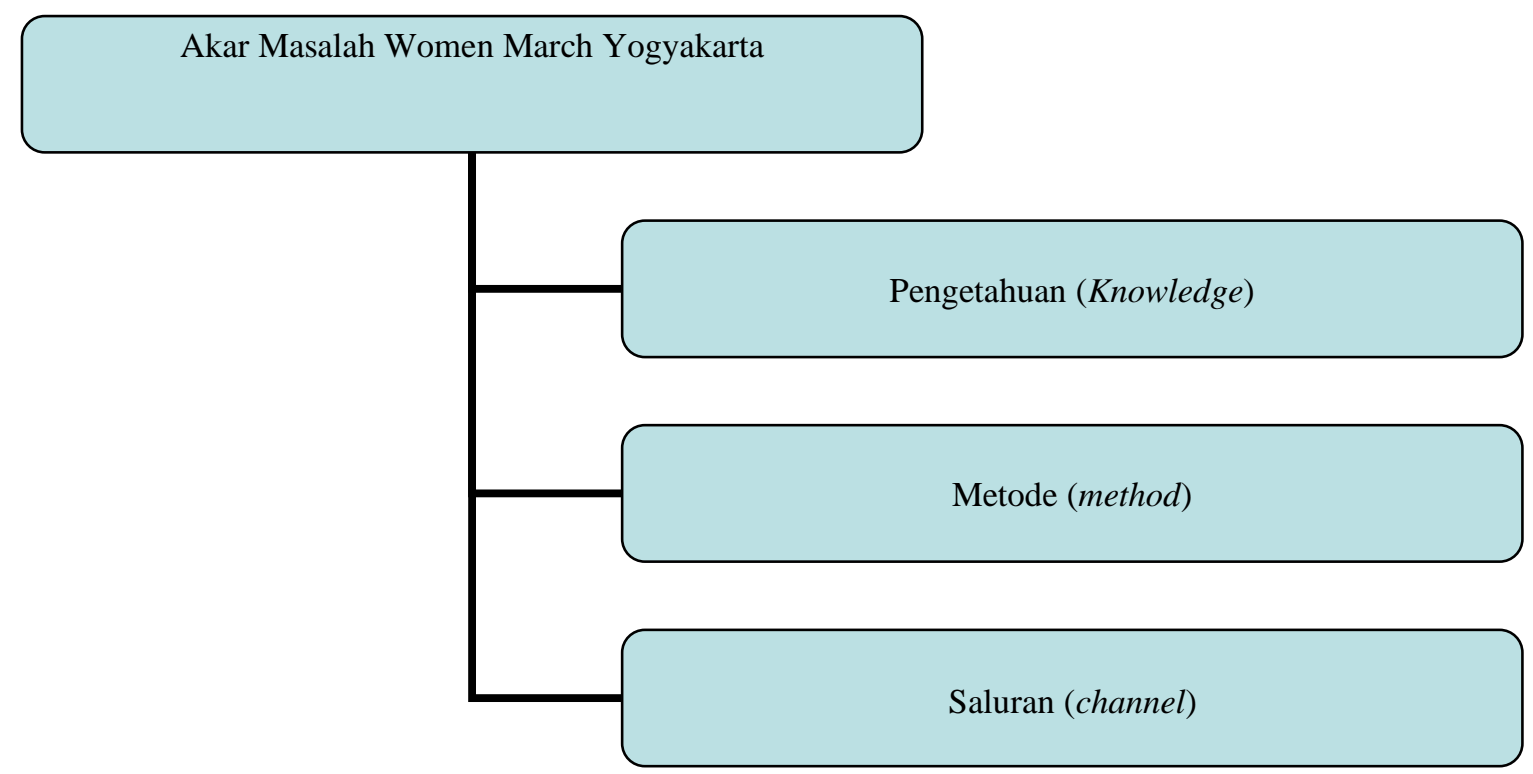

Gambar 1. Pemetaan Akar Masalah di Women March Yogyakarta

Tiga persoalan di atas dapat diatasi melalui pelatihan yang diberikan kepada komunitas melalui pelatihan yang difasilitasi oleh tim pengabdian. Pelatihan yang dilakukan melibatkan seluruh anggota komunitas dan terbagi menjadi 3 topik besar. Topik pertama merupakan topik yang bertujuan untuk memecahkan masalah pengetahuan tentang gender dan seksualitas. Topik kedua adalah pelatihan public speaking untuk meningkatkan kecakapan komunikasi publik. Public speaking merupakan 
ABDI: Jurnal Pengabdian dan Pemberdayaan Masyarakat

ISSN: 2656-369X (Print), 2684-8570 (Online)

Volume 3 No. 2, Desember 2021

http://abdi.ppj.unp.ac.id/index.php/abdi

Email: abdi@ppi.unp.ac.id

DOI: https://doi.org/10.24036/abdi.v3i2.148

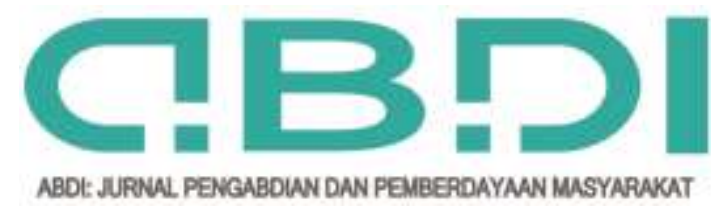

sebuah proses penyampaian pesan dari komunikator kepada publik dengan metode yang terstuktur agar dapat memberikan dampak tertentu bagi publik (Lucas, 2020). Untuk mewujudkan gerakan ini, maka seorang orator setidaknya perlu memiliki kapasitas untuk menyampaikan pesan-dalam hal ini pengetahuan, mampu menguasai audiens, dan mampu berstrategi menggunakan media untuk menyuarakan ide-idenya. Hal-hal di atas seringkali menjadi hambatan komunitas untuk melaksanakan beragam kegiatan orasi. Hambatan yang muncul berupa hambatan psikologis (karena demam panggung) dan hambatan teknis, yakni terkait dengan kemampuan mengolah pesan karena minimnya pengetahuan, pengucapan yang tidak jelas, dan volume suara yang kurang lantang.

Topik pelatihan ketiga adalah pengelolaan media sosial yang menjadi solusi atas permasalahan mengenai saluran. Salah satu strategi menjangkau audiens yang lebih luas saat ini adalah dengan menggunakan media sosial. Hal ini dikarenakan di Indonesia, jumlah pengguna media sosial terus meningkat. Data dari We Are Social tahun 2020 menunjukkan bahwa pengguna media sosial di Indonesia mencapai 175,4 juta pengguna atau naik sebesar $17 \%$ ketimbang tahun sebelumnya (Haryanto, 2020). Kietzmann, Hermkens, McCarthy, dan Silvestre (2011) mengemukakan bahwa media seperti sarang madu yang memiliki tujuh blok: kehadiran, berbagi, berelasi, menunjukkan identitas, percakapan, reputasi dan kelompok. Tujuh blok ini, jika dimanfaatkan dengan maksimal akan mendukung upaya komunitas untuk menyampaikan ide-ide tentang kesetaraan gender lebih luas. Berdasarkan persoalan di atas, tim mengadakan program pengabdian untuk meningkatkan kapasitas anggota komunitas gerakan perempuan melalui pelatihan public speaking dan pembekalan mengenai gender dan seksualitas.

Kegiatan pelatihan public speaking dan pengelolaan media di komunitas masih jarang dilakukan. Hal ini dikarenakan fokus pelatihan pada kegiatan pengabdian lain cenderung ke arah pemanfaatan teknologi komunikasi dan informasi. Beberapa kegiatan pengabdian terkait pemanfaatan teknologi komunikasi informasi antara lain dilakukan oleh Seta, Wati, dan Mardani (2018) yang memberikan pelatihan terkait konten dan e-learning kepada guru pondok pesantren. Kegiatan pelatihan dengan tema serupa juga dilaksanakan oleh Widiastiwi, Zaibidah, dan Hananto (2018) yang melaksanakan pelatihan teknologi komunikasi dan informasi pada sekolah dan mitranya adalah anakanak jalanan.

Kegiatan pengabdian lain terkait gender, cenderung menyasar perempuan di daerah rawan bencana maupun perempuan pekerja. Dua diantaranya adalah kegiatan pelatihan komunikasi antarpersona perempuan pemetik teh yang dilakukan oleh Chairiawaty dan Syam (2004). Kegiatan pelatihan yang lain diarahkan pada kegiatan penelitian untuk melihat kesiapan perempuan di daerah rawan bencana yang dilaksanakan oleh Agustina, Rachmiatie, Ekasari, Damayanti, dan Aji (2020). Fokus pada tulisan ini adalah memaparkan kegiatan pelatihan yang dilaksanakan untuk meningkatkan kapasitas public speaking anggota komunitas gerakan perempuan dan meningkatkan kemampuan pengelolaan konten media sosial untuk gerakan perempuan.

\section{Metode Pelaksanaan}

Metode pelaksanaan pengabdian masyarakat ini adalah dengan melakukan pelatihan kepada anggota komunitas Women March di Yogyakarta. Pelatihan ini dilaksanakan dalam tiga sesi materi, yakni pengetahuan gender dan seksualitas, teori dan praktik public speaking, dan pemanfaatan media sosial. Pelatihan ini diikuti oleh 30 anggota komunitas yang rentang usianya berada pada kisaran 1824 tahun atau masuk kategori remaja tingkat akhir dan dewasa. Kegiatan pengabdian ini dilakukan dengan dua metode: ceramah dan praktik, meliputi praktik public speaking (penyusunan pesan dan olah vokal), penggalian pengalaman seputar gender dan seksualitas, dan praktik pembuatan konten media sosial yang kreatif. Pada tahap evaluasi, evaluasi dilakukan melalui FGD meliputi kesan dari peserta dan saran yang diberikan kepada pemateri. Setelah evaluasi, tim pengabdian menyusun modul yang dapat dipakai oleh komunitas sebagai acuan saat pelatihan selanjutnya. 


\section{Hasil dan Pembahasan}

Pelatihan dimulai dengan pembekalan seputar gender dan seksualitas. Materi terkait gender dan seksualitas dibagi menjadi tiga materi yakni dasar-dasar gender dan seksualitas, ketidakadilan gender dan manifestasi ketidakadilan gender.

Gender merupakan konstruksi sosial yang dibangun berdasarkan jenis kelamin. Seks merupakan karakteristik biologis yang mendefinisikan seseorang menjadi perempuan dan laki-laki. Seksualitas merupakan istilah yang digunakan untuk menjelaskan kehidupan manusia yang berhubungan dengan seks dan gender meliputi identitas gender, reproduksi, dan lain sebagainya. Pada pembahasan mengenai gender, peserta pelatihan juga diberi penjelasan bahwa konstruksi masyarakat mengenai gender dan seksualitas berdampak padaadanya tindakan diskriminasi terhadap gender tertentu. Diskriminasi ini tidak lepas dari peran media juga memberi peran dalam menciptakan persepsi mengenai laki-laki dan perempuan.

Pada materi ini, peserta juga diminta untuk merefleksikan pengalaman-pengalaman mereka yang memiliki kaitan tentang gender dan seksualitas. Refleksi ini kemudian ditempelkan di kertas yang sudah disediakan dan didiskusikan. Hasil diskusi ini menunjukkan bahwa pada pengalaman empiris peserta terdapat banyak pertanyaan tentang kesehatan reproduksi yang dianggap tabu dan dianggap bahwa nantinya seseorang akan mengetahui hal tersebut saat sudah dewasa.

Hal ini menunjukkan bahwa budaya tabu memberikan hambatan-hambatan edukasi masyarakat tentang gender dan seksualitas. Isu mengenai gender dan seksualitas tidak pernah dibahas secara terbuka, padahal sejatinya memahami gender dan seksualitas berarti berupaya memahami tubuh masing-masing.

Materi kedua adalah tentang Ketidaksetaraan gender yang merupakan sistem dan struktur hirarki yang muncul di sebuah relasi, dimana laki-laki dan perempuan menjadi korban dari sistem tersebut. Manifestasi ketidaksetaraan gender berupa Marginalisasi (proses peminggiran yang mengakibatkan kemiskinan), Subordinasi (Kondisi peminggiran gender dalam keputusan politik), stereotipe,kekerasan, dan beban ganda (Fakih, 2015). Diskusi yang berjalan terkait materi ini adalah pro kontra bentuk kekerasan (misalnya sunat perempuan) yang pada pandangan agama tertentu justru diperbolehkan karena dinggap penting untuk mengontrol nafsu perempuan. Diskusi ini kemudian dibahas dari segi kesehatan, dimana sunat perempuan tidak memiliki alasan medis seperti sunat pada laki-laki. Justru persoalan kontrol terhadap perempuan ini menjadi hal yang seharusnya dikritisi, bagaimana agama berupaya untuk mengontrol tubuh individu bahkan pada persoalan seksualitas.

Pelatihan berikutnya adalah pelatihan public speaking. Pelatihan ini diawali dengan pembahasan terkait tujuan public speaking (Lucas, 2020), antara lain:

1. Membuat audiens mendengar/melihat pesan yang disampaikan

2. Membuat audiens memahami pesan

3. Membuat audiens menyetujui pesan

4. Membuat audiens melakukan tindakan sesuai pesan yang diberikan

5. Memperoleh umpan balik dari audiens. 
ABDI: Jurnal Pengabdian dan Pemberdayaan Masyarakat ISSN: 2656-369X (Print), 2684-8570 (Online)
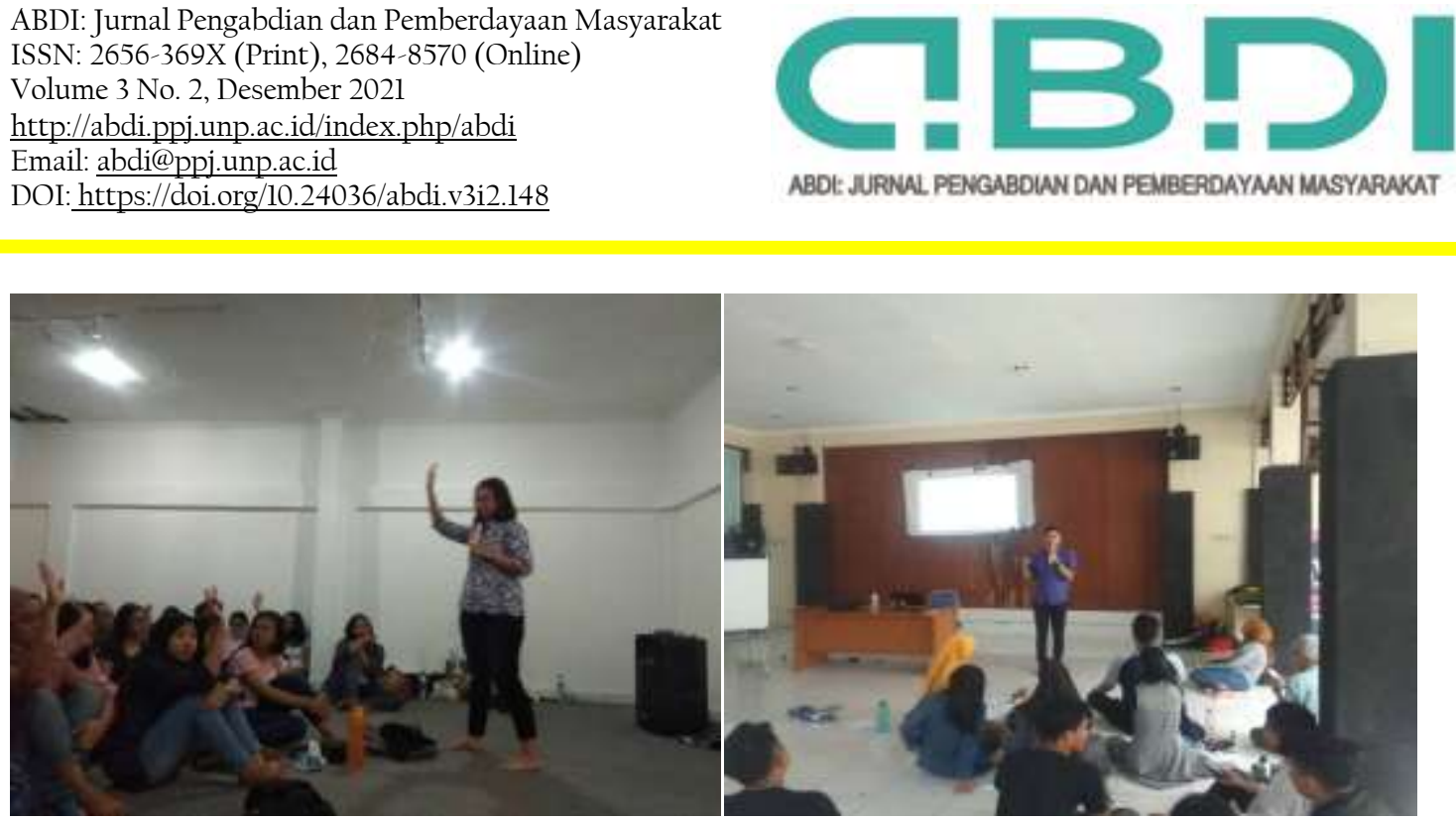

Gambar 2. Suasana pelatihan public speaking

Setelah memahami tujuan, peserta diajak untuk merefleksikan hal-hal yang menjadi penghambat public speaking. Temuan yang muncul adalah seputar hambatan psikologis, seperti gugup, demam panggung, yang menyebabkan komunikator lupa materi yang akan disampaikan. Selain itu, hambatan yang muncul adalah terkait vokal dan artikulasi. Melalui pemetaan hambatan, pemateri memberikan cara-cara mengatasi hambatan tersebut, salah satunya dengan latihan olah vokal.

Pelatihan yang terakhir adalah tentang pengelolaan konten media sosial. Perlu strategi dalam memperjuangkan sesuatu hal melalui media sosial. Pemanfaatan media sosial mencari cara yang strategis untuk menyebarkan ide-ide. Hal ini dikarenakan beberapa faktor, yakni:

- 171 juta orang menggunakan internet pada tahun 2018, dengan kata lain, 64,8\% lebih penduduk telah mengenal internet dengan rentang usia 18-34 tahun (APJII, 2018).

- Berdasarkan hasil survei, Youtube adalah media sosial yang paling banyak digunakan. Peringkat kedua adalah Whatasapp dan diikuti oleh Facebook, Instagram, Line dan lain sebagainya.

- Keberadaan media sosial penting karena secara data orang-orang telah meninggalkan media konvensional.

- Media sosial saat ini digunakan sebagai tempat untuk mencari teman, bersosialisasi, dan mengelola hubungan yang baik. Akan tetapi media sosial juga menjadi tempat orang untuk menunjukkan pada orang lain bahwa dirinya paling benar, menghakimi orang lain dan pada akhirnya menciptakan permusuhan.

Permasalahan yang dihadapi adalah sebagian besar orang tidak bijak dalam bermedia. Saat ini emosi pengguna lebih besar daripada logika, juga hatespeech yang memiliki dampak buruk bagi diri sendiri maupun orang lain.Berangkat dari persoalan ini, maka perlu ada proses edukasi melalui tulisan. Sebagai komunitas yang bergerak di isu gender, upaya pengelolaan konten media sosial merupakan cara yang strategis yang dapat dilakukan oleh komunitas ini. Hal-hal penting yang perlu diperhatikan saat mengelola konten media sosial antara lain tentang komunikan, strategi pesan, dan waktu yang tepat untuk mempublikasikan pesan.

Setelah penjelasan mengenai media sosial ini, pemateri meminta peserta membentuk kelompok lalu setiap kelompok diberikan satu foto untuk dibuatkan pesan dengan memperhatikan elemenelemen storytelling yang sudah dijelaskan. Lalu perwakilan kelompok mempresentasikan hasil kreativitas kelompoknya. Lalu pemateri memberikan evaluasi dari masing-masing caption yang sudah dibuat.

Setelah seluruh materi selesai, peserta melakukan evaluasi dari hasil pelatihan. Evaluasi yang diberikan lebih mengarah ke persoalan teknis seperti tempat pelatihan yang terlalu terbuka, noise yang cukup banyak sehingga mengganggu konsentrasi. Secara keseluruhan, kegiatan pengabdian telah 
berjalan dengan baik, hal ini dapat dilihat dari antusiasme para peserta untuk hadir dan bertahan mengikuti rangkaian pelatihan dan aktif berdiskusi melalui forum tanya jawab dan pada saat praktik public speaking dan pembuatan konten media sosial.

Setelah selesai melaksanakan kegiatan pengabdian, tim membuat luaran berupa modul ajar public speaking dan pemanfaatan media bagi komunitas yang bergerak pada isu gender dan kesehatan reproduksi. Modul ini memiliki dua tujuan utama, yakni: Pertama, memberikan pengetahuan dasar mengenai gender, seksualitas dan kesehatan reproduksi. Materi ini merupakan materi dasar berpikir kritis tentang isu gender. Kedua, tujuan praktis, meningkatkan kecakapan berkomunikasi di depan publik dan di media sosial melalui materi teori dan praktik public speaking dan penyusunan pesan pada konten media sosial

Secara teknis, kegiatan pengabdian telah terlaksana dengan baik. Hal ini dikarenakan pada proses persiapan, tim pengabdian melakukan pendekatan dan diskusi yang mendalam dengan mitra. Penggalian informasi dan identifikasi masalah yang dialami oleh mitra tidak dilakukan hanya satu kali pertemuan, melainkan dua kali dengan mengajak lebih banyak anggota untuk terlibat dalam diskusi dan menyampaikan pandangannya. Selain itu, pada proses persiapan, tim juga didukung oleh universitas melalui skema pendanaan kegiatan pengabdian untuk pengadaan peralatan yang dibutuhkan selama pelatihan.

Dari sisi tim pengabdian, keberhasilan pelaksanaan pengabdian ini ditentukan pula oleh persiapan dan diskusi internal tim. Diskusi internal tim dilakukan dalam rangka menyeleksi materi yang tepat untuk disampaikan pada saat pelatihan. Tim juga melakukan proses peer review materi, dengan tujuan setiap anggota tim pengabdian mampu memberikan masukan agar materi dapat disampaikan dengan efektif.

\section{Kesimpulan}

Kegiatan pengabdian kepada masyarakat berupa pelatihan public speaking dan pemanfaatan media untuk gerakan perempuan dapat meningkatkan kecakapan public speaking dan pengelolaan konten media sosial sehingga ide-ide komunitas dapat dibaca oleh audiens yang lebih luas. Pelatihan ini dilakukan melalui dua tahap: penggalian akar masalah dan praktik pelatihan. Diskusi penggalian akar masalah membantu tim pengabdian untuk menyusun materi dan menentukan metode pelatihan yang tepat untuk komunitas mitra. Pelatihan yang sudah dilaksanakan membantu komunitas Women March Yogyakarta untuk berstrategi menyusun dan membagikan pesan dan disesuaikan dengan konteks komunikasi dan media yang digunakan. Pada masa yang akan datang, pendampingan lanjutan yang dapat dilakukan adalah pendampingan untuk merancang konten di media lain seperti membuat video kampanye dan tulisan di blog agar pesan terkait isu gender ini dapat disampaikan dengan lebih lengkap dan jelas.

\section{Daftar Pustaka}

Agustina,I.H., Rachmiatie, A., Ekasari, A.M., Damayanti, V., dan Aji, R.R. (2020). Gender dan Mitigasi Bencana di Desa Cikole Kecamatan Lembang Kabupaten Bandung Barat. Jurnal Ethos, 8(2), 313-318.

APJII. (2018). Laporan Survei Penetrasi \& Perilaku Pengguna Internet Indonesia. < https://www.apjii.or.id/content/read/39/410/Hasil-Survei-Penetrasi-dan-Perilaku-PenggunaInternet-Indonesia-2018>.

Fakih, M. (2015). Analisis Gender dan Transformasi Sosial. Yogyakarta: Pustaka Pelajar.

Haryanto, A. T. (2020). Ada 175,2 juta pengguna internet di Indonesia. <https://inet.detik.com/cyberlife/d-4907674/riset-ada-1752-juta-pengguna-internet-diindonesia>

Kietzmann, J.H., Hermkens, K., McCarthy,I.P., dan Silvestre, B. (2011). Social Media? Get Serious! Understanding the Functional Building Blocks of Social Media. Business Horizon, 54, 241-251.

Lucas, S.E. (2020). The Art of Public Speaking. New York: McGraw Hill. 
ABDI: Jurnal Pengabdian dan Pemberdayaan Masyarakat ISSN: 2656-369X (Print), 2684-8570 (Online)

Volume 3 No. 2, Desember 2021

http://abdi.ppj.unp.ac.id/index.php/abdi

Email: abdi@ppj.unp.ac.id

DOI: https://doi.org/10.24036/abdi.v3i2.148

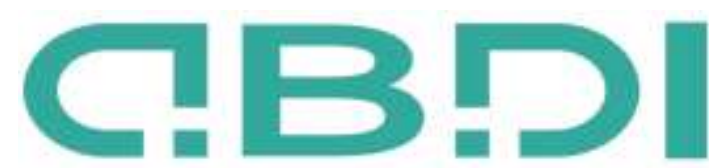

ABDL: JURNAL PENGABOIN DAN PEMBERDAYMN MUSYARAKAT

Narda, R. Menteri PPPA: Masih Banyak Kekerasan Diskriminasi Terhadap Perempuan di 2019. $<$ https://news.detik.com/berita/d-4828631/menteri-pppa-masih-banyak-kekerasan-diskriminasiterhadap-perempuan-di-2019>

Purnamasari, D.M. (2020). Catatan Komnas Perempuan 431.471 Kasus Kekerasan Terjadi Sepanjang Tahun 2019. <https://nasional.kompas.com/read/2020/03/06/15134051/catatan-komnasperempuan-431471-kasus-kekerasan-terjadi-sepanjang-2019?page=all $>$

Seta, H.B., Wati, T., Mardani, I. (2018). Membangun E-Learning Berbasis Intranet untuk Mewujudkan Konsep Boarding School Teknologi Informasi dan Komputer. Jurnal Ethos, 6(1), 24-32.

Chairiawaty dan Syam, N.K. (2004). Keefektifan Komunikasi Antarpersona Wanita Pemetik Teh dan Ketertarikannya dengan Partisipasi Sosial mereka dalam Kegiatan Kemasyarakatan di Desa Warnasari. Jurnal Ethos, 2(1), 65-81.

Widiastiwi, Y., Zaibidah, A., Hananto, B. (2018). Peningkatan Kemampuan Teknologi Informasi dan Komunikasi (TIK) Bagi Anak Jalanan Sekolah Master Insan Mandiri (YABIM).Jurnal Ethos, 6(1), 101-106

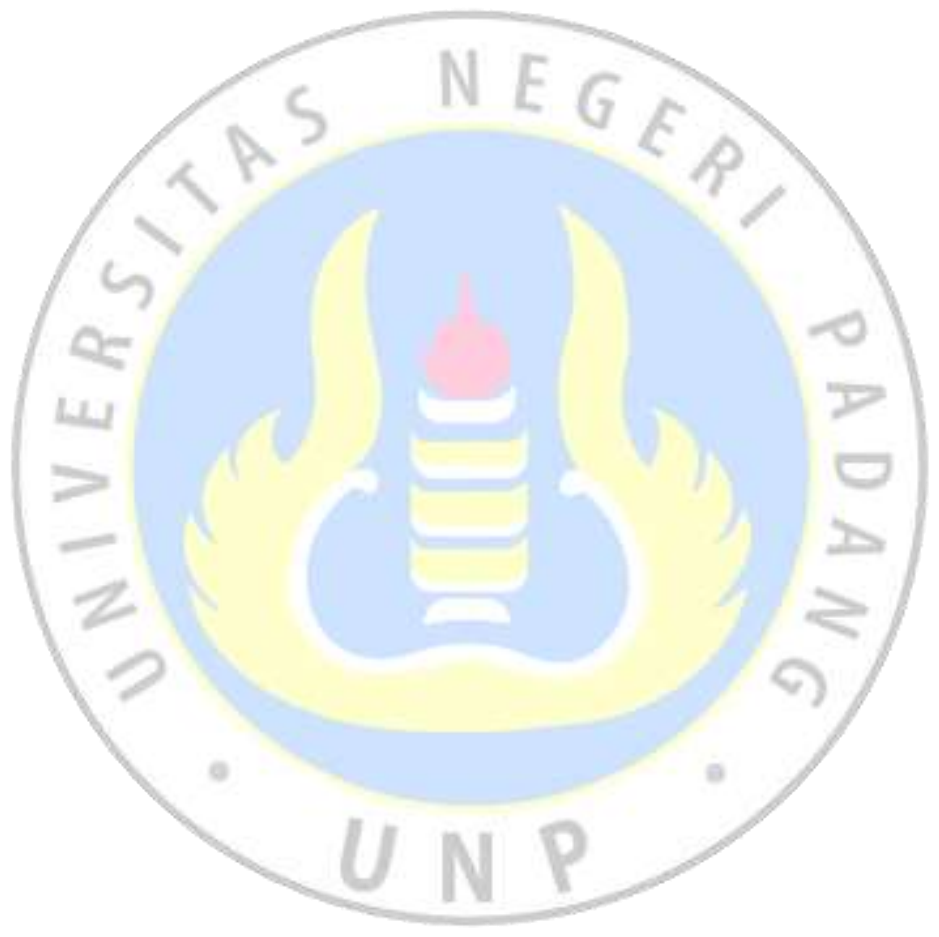

